\title{
Selected Ratio and Bankruptay Early-Warning Method Analysis of Competitiveness of Wood Sector Companies Listed on Warsaw Stock Exchange
}

\section{Analiza konkurentnosti tvrtki drvnog sektora koje su na Varšavskoj burzi metodom odabranog omjera i ranog upozorenja o bankrotu}

Original scientific paper • Izvorni znanstveni rad

Received-prispjelo: 15. 3. 2012.

Accepted-prihvaćeno: 6. 9. 2012.

UDK: $630 * 79$

doi:10.5552/drind.2012.1212

\begin{abstract}
This paper presents the analysis of economic conditions of wood sector companies listed on the Warsaw Stock Exchange. Among many measures of ratio analysis, the three most frequently used groups of indicators - profitability, debt and liquidity were selected. For a comprehensive presentation of the situation of each company, the Maczyńska \& Zawadzki's model was used as the bankruptcy early warning method. Two furniture industry companies, two wood-based panel industry companies, two pulp and paper industry entities, a representative of sawmilling industry and a company of wood-based panels and furniture industry were analyzed. The analysis showed that companies with stabile position in the market have the best economic conditions, and these were namely the pulp and paper industry and furniture industry.
\end{abstract}

Keywords: ratio analysis, bankruptcy early-warning methods, competitiveness, wood sector companies

SAŽETAK • Ovaj rad sadrži analizu ekonomskih uvjeta u tvrtkama drvnog sektora koje se nalaze na Varšavskoj burzi. Među mnogim metodama mjerenja i analize omjera odabrane su tri najčešće skupine indikatora - profitabilnost, dugovanja i likvidnost. Za sveobuhvatnu prezentaciju situacije u pojedinoj tvrtki u proračunavanju ranog upozorenja bankrota odabran je model Maczynska \& Zawadzki. Analizirane su dvije tvrtke proizvodnje namještaja, dvije trtke za proizvodnju drvnih ploča, dvije tvrtke u području proizvodnje pulpe i papira, jedan predstavnik pilana i jedna tvrtka koja proizvodi i namještaj i drvne ploče. Analiza je pokazala da najbolje ekonomske uvjete imaju tvrtke sa stabilnom pozicijom na tržištu među koje pripadaju tvrtke za proizvodnju pulpe i papira te za proizvodnju namještaja.

Ključne riječi: analiza omjera, metode ranog upozorenja bankrota, konkurentnost, tvrtke drvnog sektora

\footnotetext{
Author is assistant at Faculty of Wood Technology, Warsaw University of Life Sciences, Warsaw, Poland. ${ }^{2}$ Autor is the assistant at Faculty of Wood Science and Technology, Technical University, Zvolen, Slovak Republic.

Autorica je asistentica Fakulteta drvne tehnologije Varšavskog sveučilišta bioloških znanosti, Varšava, Poljska. ${ }^{2}$ Autorica je asistentica Fakulteta znanosti o drvu i tehnologiji, Tehničko sveučilište, Zvolen, Slovačka.
} 


\section{INTRODUCTION}

\section{UVOD}

Taking cooperation with a contractor in any kind of project or investing funds in a company shares is a very important decision to be made by the investor. The results of this decision may affect the amount of profits, losses and may even determine decisions taken by the company management in the subsequent periods. To reduce the probability of making wrong decisions, a potential investor can use a variety of proven and frequently used methods (Jelačić et al., 2006). One of the most used and best known method is: ratio analysis - an element of financial analysis and a more powerful tool - the discriminant analysis using early warning models (Sedliačikova et al., 2006). Financial data are the best indication of company problems, especially the falling profits and losses can be seen as a deteriorating level of competitiveness compared to other industry representatives (Bednarski, 2002; Dębski, 2005; Michalski, 2005; Tyran, 2004).

This paper presents the analysis of the economic condition of wood industry companies listed on the Warsaw Stock Exchange.

\section{MATERIALS AND METHODS 2. MATERIJALI I METODE}

The analysis included the representatives of the furniture industry: „A” and „B”, the wood-based panel industry: „C" and „D”, representatives of the pulp and paper industry: „E” and „F”, the sawmill industry: „G” and ,H”, working in the wood-based panel and furniture industry. The main selected indicators of ratio analysis and Mączyńska \& Zawadzki’s polynomial were calculated. The calculations were based on data from the annual financial statements of the analyzed companies from the period 2008-2010. For the purpose of solving the decision tasks related to the optimization of output assortments, it is necessary to show separately variable costs influenced by changes in volume of production and fixed costs not influenced by changes in volume of production (Potkany, 2005).

The representative of the furniture industry - „B”, founded in 1992 by Maciej Formanowicz in Ostrów Mazowiecka, was the first analyzed company. „B” is the top Polish manufacturer and exporter of furniture, owning four manufacturing facilities in Poland and ten sales companies. The company employs more than 2000 employees. The export generates about $80 \%$ of the company sales revenues. The main product of „B” is cabinet furniture, whose sales value is over $90 \%$ of total company sales.

The representative of the furniture industry - „A" was the second analyzed company. The company started business in 1993, and it was engaged in the production of beds for children and infants. Gradually, the production of furniture for children was expanded to include wood-based panel furniture for children rooms, such as: cabinets, dressers, bookshelves and desks. Furthermore, the company produces textiles for chil- dren. The company has been listed on the stock exchange since 2008.

Further representatives of timber industry are classified as wood-based panel companies and these are: „C" and ,D”.

„C" belongs to an international corporation Pfleiderer. The company includes factories in Grajewo, Wieruszów, Veliky Novgorod (Russia) and the glue factory Silekol in Kędzierzyn-Koźle. The company production includes a wide range of laminated and veneered boards, raw and laminated HDF, high-pressure laminates HPL, new on the Polish market - MFP building boards, furniture foils and adhesive resins.

„D” specializes in the production of wet-processed hardboards. The company production also includes raw hardboards, single color lacquered hardboards and hardboards lacquered in the wood structure. The company was founded in 1970. „D” entered the Warsaw Stock Exchange in 2008 and employs almost 430 people.

„E” is a pulp and paper company that was founded in 1989. The first listing of the company's shares on the stock exchange took place in 1996. „E” produces articles intended for office applications, for example: printing materials, including general forms (for example: invoices), printer paper, paper rolls used in cash registers, faxed and mobile printers.

„F” was set up in 1961 under the name of Zakłady Celulozy i Papieru in Świecie. The company's shares were listed for public trading on the Warsaw Stock Exchange in 1997. In 2008 the name of the company was changed. In 2010, the company's output was 1,313 thousand tons of corrugated and sack paper.

„G" has been engaged in wood industry for 60 years. The main company's products are: edged and unedged sawn timber, fresh, dried, planed and treated, construction elements for roofs and house constructions, glued elements, sleepers, floor boards, wainscot, skirting boards, elements for furniture production and other goods, small garden architecture. Pine, beech and oak are mostly used as raw materials. Spruce, birch, ash and hornbeam are also processed in smaller quantities.

„H” is a company dedicated to designing, manufacturing and distribution of furniture, plywood and lumber and wood-based boards trade. The commercial unit of the company is located in Warsaw. Designing and furniture manufacturing takes place in Jasienica the headquarters of the company „H”. The production of plywood takes place in plywood mills „H” in Morag. The Group „H” includes: 3 plants producing plywood, 3 plants producing furniture, 2 foreign trade companies and 16 commercial warehouses in Poland. „H” offers a wide range of plywood, furniture and wood-based panels such as: chairs, stools, tables, plywood, veneer, joinery, HDF, MDF, OSB and others.

The basic indicators of ratio and Mączyńska \& Zawadzki's polynomial analysis were used for the calculations. The calculations were based on public data from the annual financial statements of the analyzed companies listed on the Warsaw Stock Exchange in the period 2008-2010. The calculations were performed using Excel. The chosen indicators can be easily ap- 
Table 1 Indicators of ratio analysis used in calculations

Tablica 1. Pokazatelji analize omjera upotrijebljenih u kalkulacijama

\begin{tabular}{|c|c|c|c|}
\hline $\begin{array}{l}\text { Number } \\
\text { Redni broj }\end{array}$ & $\begin{array}{l}\text { Ratios group } \\
\text { Skupina omjera }\end{array}$ & Ratio / Omjer & Definition / Definicija \\
\hline \multirow[t]{3}{*}{1} & \multirow[t]{3}{*}{$\begin{array}{l}\text { Profitability ratios } \\
\text { udjeli profitabilnosti }\end{array}$} & $\begin{array}{l}\text { return of equity - ROE } \\
\text { povrat kapitala }\end{array}$ & $\begin{array}{l}\text { Net profit/equity } \\
\text { neto dobit/kapital }\end{array}$ \\
\hline & & $\begin{array}{l}\text { return of assets - ROA } \\
\text { povrat sredstava }\end{array}$ & $\begin{array}{l}\text { Net profit/total assets } \\
\text { neto dobit/ukupna sredstva }\end{array}$ \\
\hline & & $\begin{array}{l}\text { return of sales - ROS } \\
\text { povrat od prodaje }\end{array}$ & $\begin{array}{l}\text { Net profit/sales revenue } \\
\text { neto dobit/prihod od prodaje }\end{array}$ \\
\hline \multirow[t]{3}{*}{2} & \multirow[t]{3}{*}{$\begin{array}{l}\text { Debt ratios } \\
\text { udjeli dugovanja }\end{array}$} & $\begin{array}{l}\text { debt ratio } \\
\text { omjer dugovanja }\end{array}$ & $\begin{array}{l}\text { Total liabilities/total assets } \\
\text { ukupne obveze/ukupna sredstva }\end{array}$ \\
\hline & & $\begin{array}{l}\text { debt to equity ratio } \\
\text { omjer dugovanja prema kapitalu }\end{array}$ & $\begin{array}{l}\text { Long-term liabilities + short-term liabilities/equity } \\
\text { dugotrajne obveze + kratkotrajne obveze/ kapital }\end{array}$ \\
\hline & & $\begin{array}{l}\text { long term debt ratio } \\
\text { omjer dugotrajnog dugovanja }\end{array}$ & $\begin{array}{l}\text { Long-term liabilities/equity } \\
\text { dugotrajne obveze/kapital }\end{array}$ \\
\hline \multirow[t]{3}{*}{3} & \multirow[t]{3}{*}{$\begin{array}{l}\text { Liquidity ratios } \\
\text { udjeli likvidnosti }\end{array}$} & $\begin{array}{l}\text { current ratio } \\
\text { trenutačni omjer }\end{array}$ & $\begin{array}{l}\text { Current assets/long-term liabilities } \\
\text { trenutačna sredstva/dugotrajne obveze }\end{array}$ \\
\hline & & $\begin{array}{l}\text { quick ratio } \\
\text { brzi omjer }\end{array}$ & $\begin{array}{l}\text { Current assets-supplies-prepayments/short-term } \\
\text { liabilities / trenutačna sredstva-ponuda- } \\
\text { pretplaćanje/ kratkotrajne obveze }\end{array}$ \\
\hline & & $\begin{array}{l}\text { cash to debt ratio } \\
\text { omjer gotovine u dugovanju }\end{array}$ & $\begin{array}{l}\text { Cash equivalents/short-term liabilities } \\
\text { ekvivalenti gotovine/kratkotrajne obveze }\end{array}$ \\
\hline
\end{tabular}

Source: based on Sierpińska and Jachna (2004)

plied and compared with various values of companies assets (Jerzemowska, 2004; Stępień, 2008; Stradomski, 2004). The list of indicators and their definition are shown in Table 1.

\section{RESULTS AND DISCUSSION}

\section{REZULTATI I RASPRAVA}

The results of calculation of profitability ratios for stock-listed wood processing companies are shown at Figure 1 and Figure 2.

The analysis of Figure 1 and Figure 2 shows that the best results in the field of profitability are achieved by the company „F”. In the year 2010, only this company achieved positive values of all profitability indicators, namely: return of equity ratio reached 0.17 ; return of assets ratio and return of sale ratio both reached 0.11 . This mean that the company has made from 0.11 to
0.17PLN of net profit for each 1PLN invested equity, assets or sales revenues. In contrast, the year 2010 was not good for the second representative of pulp and paper industry - „E”. This company reached the highest values of profitability ratios in 2008, for example - the return of sales revenues value reached 0.17 . Particularly low values of profitability ratios were achieved by the furniture industry company - „A”. This situation can be explained by the increasing financial losses. For wood-based board companies, such as „C” and „D”, the year 2010 was the weakest year in terms of values of profitability ratios. This means that the economic crisis was not avoided by companies in woodworking industry.

Debt ratios were the second group of the calculated ratio indicators. The results of calculations are illustrated in Figure 3 and Figure 4.

The analysis of Figure 3 and Figure 4 shows that the worst values of debt ratios are achieved by „H”,
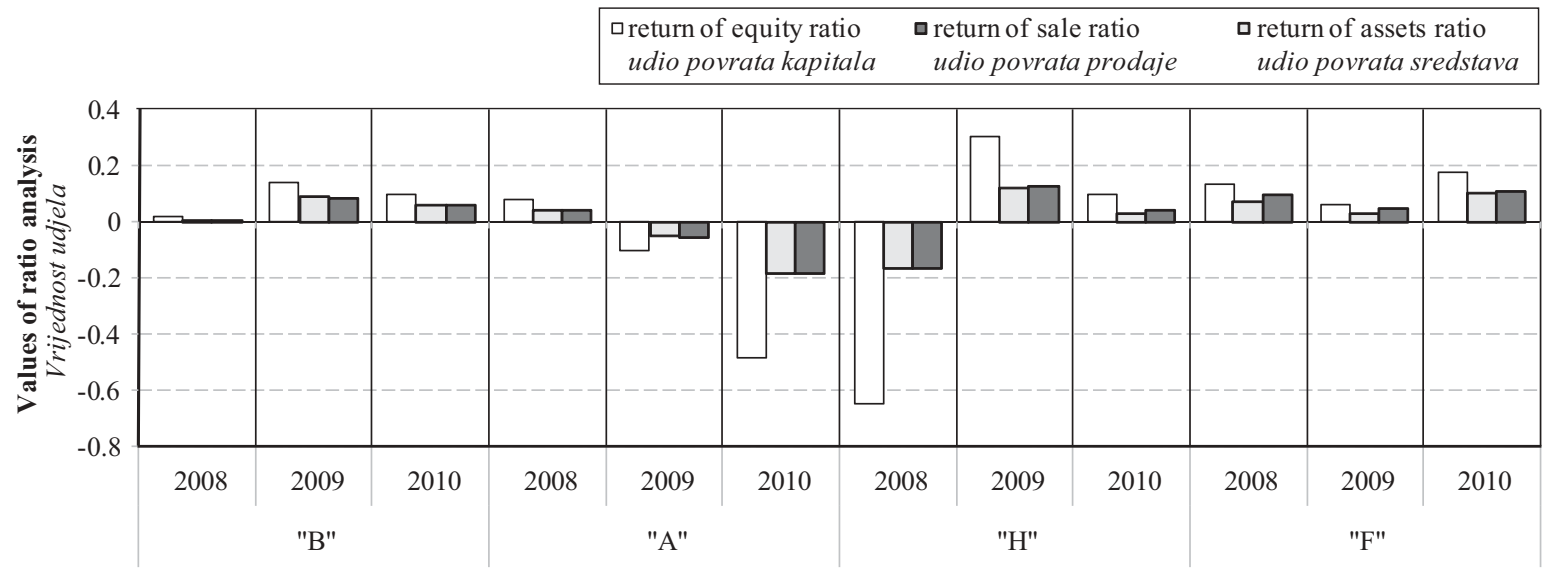

Companies results in subsequent years / Rezultati tvrtki po godinama

Figure 1 Results of analysis of the selected profitability ratios of wood sector companies „B”, „A”, „H”, „F” listed on Warsaw Stock Exchange

Slika 1. Rezultati analize odabranih omjera profitabilnosti za „B”, „A”, „H”, „F” tvrtke drvnog sektora na Varšavskoj burzi 


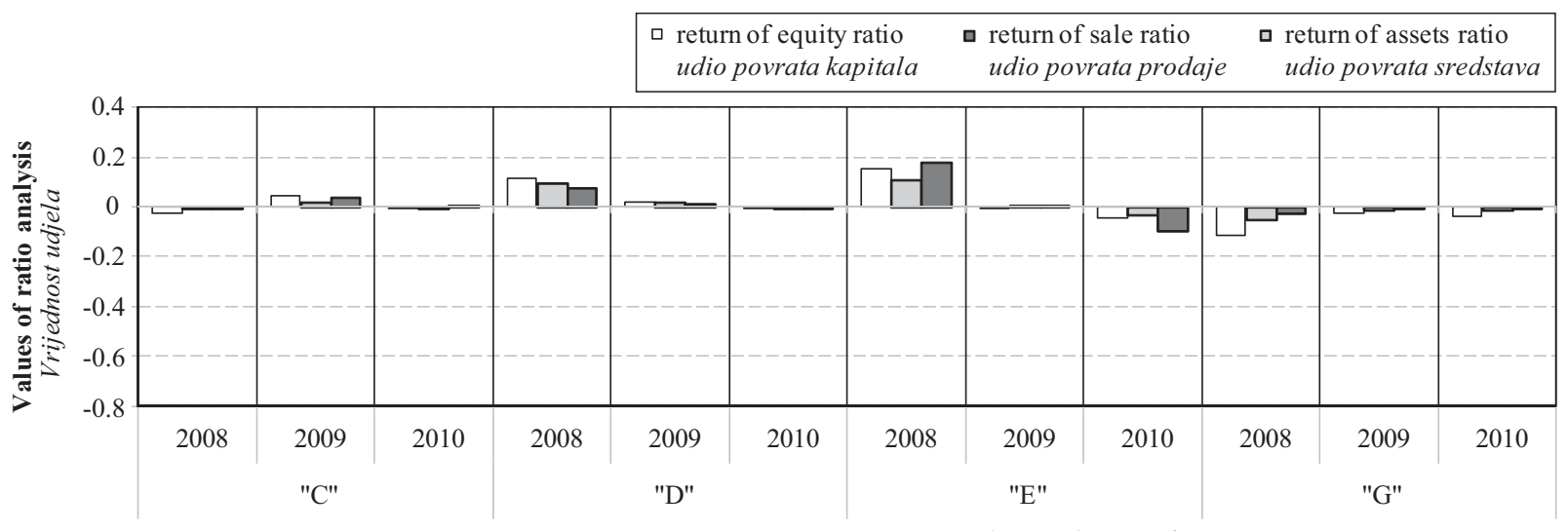

Companies results in subsequent years / Rezultati tvrtki po godinama

Figure 2 Results of analysis of the selected profitability ratios of wood sector companies „C”, „D”, „E”, „G” listed on Warsaw Stock Exchange

Slika 2. Rezultati analize odabranih omjera profitabilnosti za „C”, „D”, „E”, „G” tvrtke drvnog sektora na Varšavskoj burzi

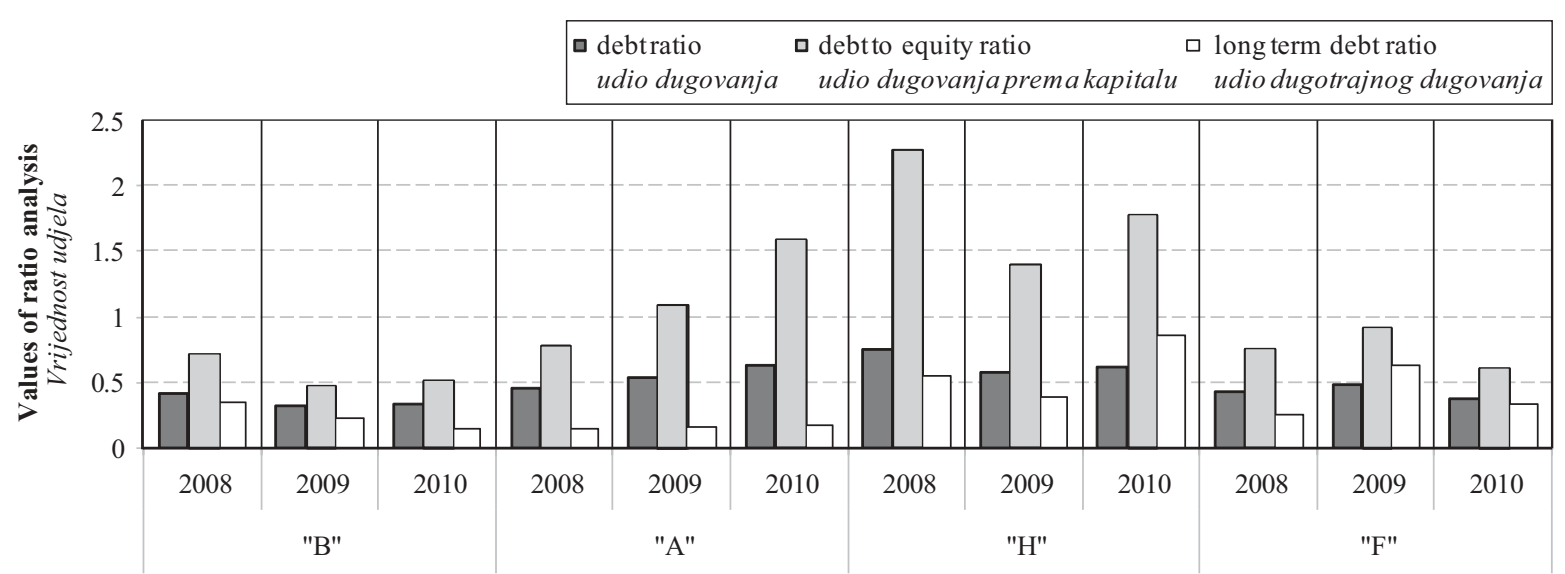

Companies results in subsequent years / Rezultati tvrtki po godinama

Figure 3 Results of analysis of the selected debt ratio of wood sector companies „B”, „A”, „H”, „F” listed on Warsaw Stock Exchange

Slika 3. Rezultati analize odabranih omjera dugovanja za „B”, „A”, „H”, „F” tvrtke drvnog sektora na Varšavskoj burzi

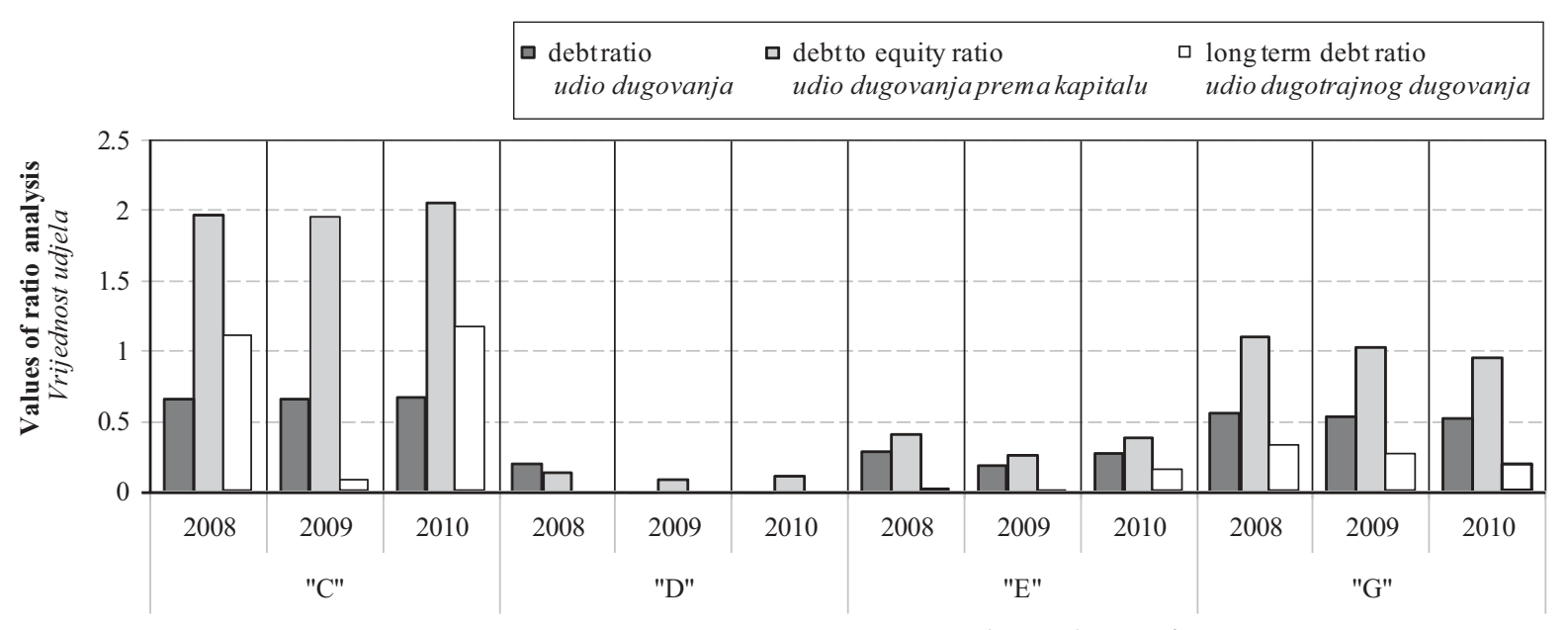

Companies results in subsequent years / Rezultati tvrtki po godinama

Figure 4 Results of selected debt ratio analysis of „C”, „D”, „E”, „G” wood sector companies listed on Warsaw Stock Exchange

Slika 4. Rezultati analize odabranih omjera dugovanja za „C”, „D”, „E”, „G” tvrtke drvnog sektora na Varšavskoj burzi 


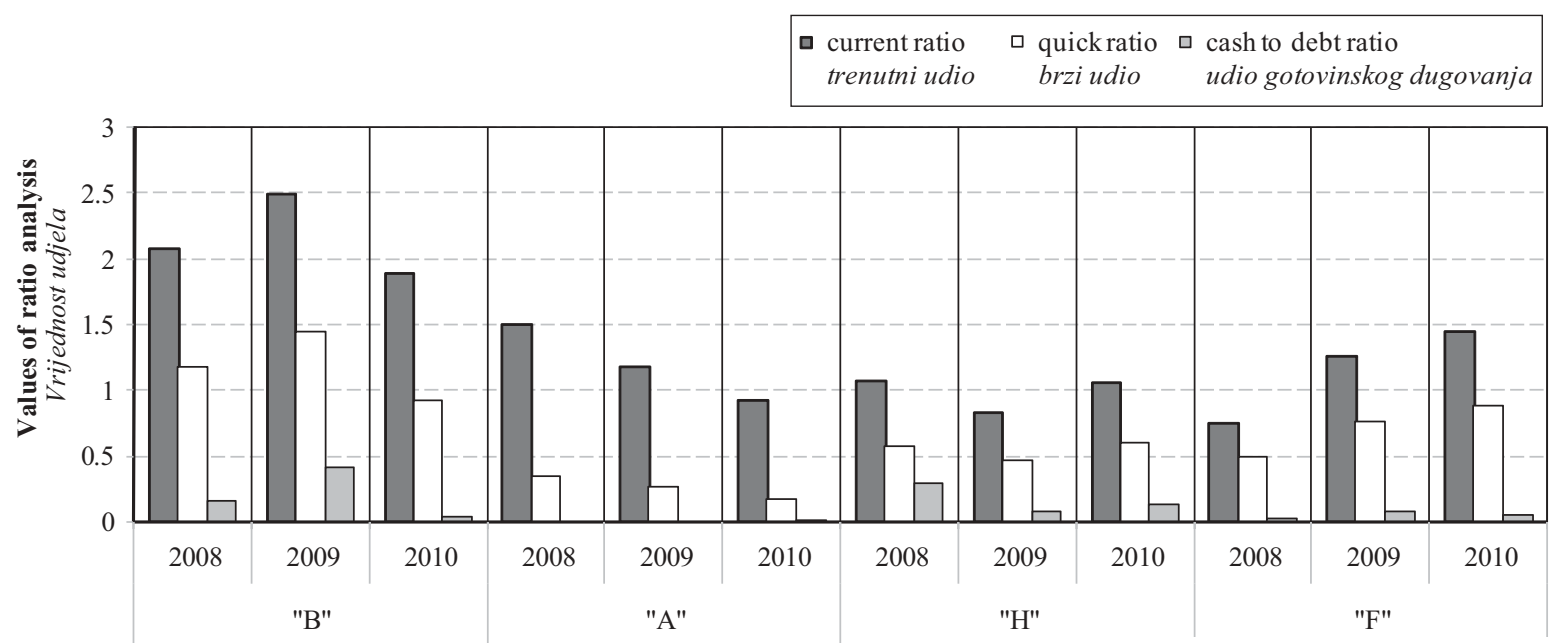

Companies results in subsequent years / Rezultati tvrtki po godinama

Figure 5 Results of analysis of the main liquidity ratios of wood sector companies „B”, „A”, „H”, „F” listed on Warsaw Stock Exchange

Slika 5. Rezultati analize omjera osnovne likvidnosti za „B”, „A”, „H”, „F” tvrtke drvnog sektora na Varšavskoj burzi

„C" and „A". These companies achieved especially high values for debt to equity ratios. For example, debt to equity ratio values for „H” ranged between 2.29 in 2008 and 1.41 in 2009. The year 2010 was worse for the company than the year 2009 - the value of debt to equity ratio increased to 1.78 . The values of debt to equity ratios indicate that the total liabilities are almost twice the value of the equity. The lowest values of debt ratios were achieved by „D”, ,E” and „B". The equity is covered by liabilities in a small extent for „D" (from 9 to $14 \%$ ) and for „E” (from 26 to $41 \%$ ) while for „B” it reaches $48-72 \%$.

Liquidity ratios are the last group of indicators calculated in this paper. The results of liquidity ratio analysis are shown in Figure 5 and Figure 6.

As shown by the analysis of Figure 5 and Figure 6 , the current assets cover the long-term liabilities to the highest degree in companies „B” and „D”. Current ratio values for „B” are the highest in the years 2008 and 2009 (2.08 and 2.50, respectively) and for „D” in the years 2009 and 2010 (3.97 and 5.55, respectively). The lowest values of current ratio are observed for „C" - in subsequent years of analysis the company reached: 0.20 in 2008; 0.20 in 2009 and 0.43 in 2010, respectively.

The highest values of a more critical indicator, namely quick ratio, were also observed for companies „D” and „B”. The current assets without supplies have covered short-term liabilities of „D” more than 2 or even 3 times, in „B” they covered short-term liabilities about $100 \%$. The sawmill company ,G” shows very good results of liquidity ratios and „F" shows increasing values.

Ratio analysis provides a specific range of information to a researcher. Therefore, early warning bankruptcy models are often used to provide a general insight into the economic condition of a company. Most early warning methods, also called discriminant models, are based on a polynomial structure using the combination of some independent variables and their assigned

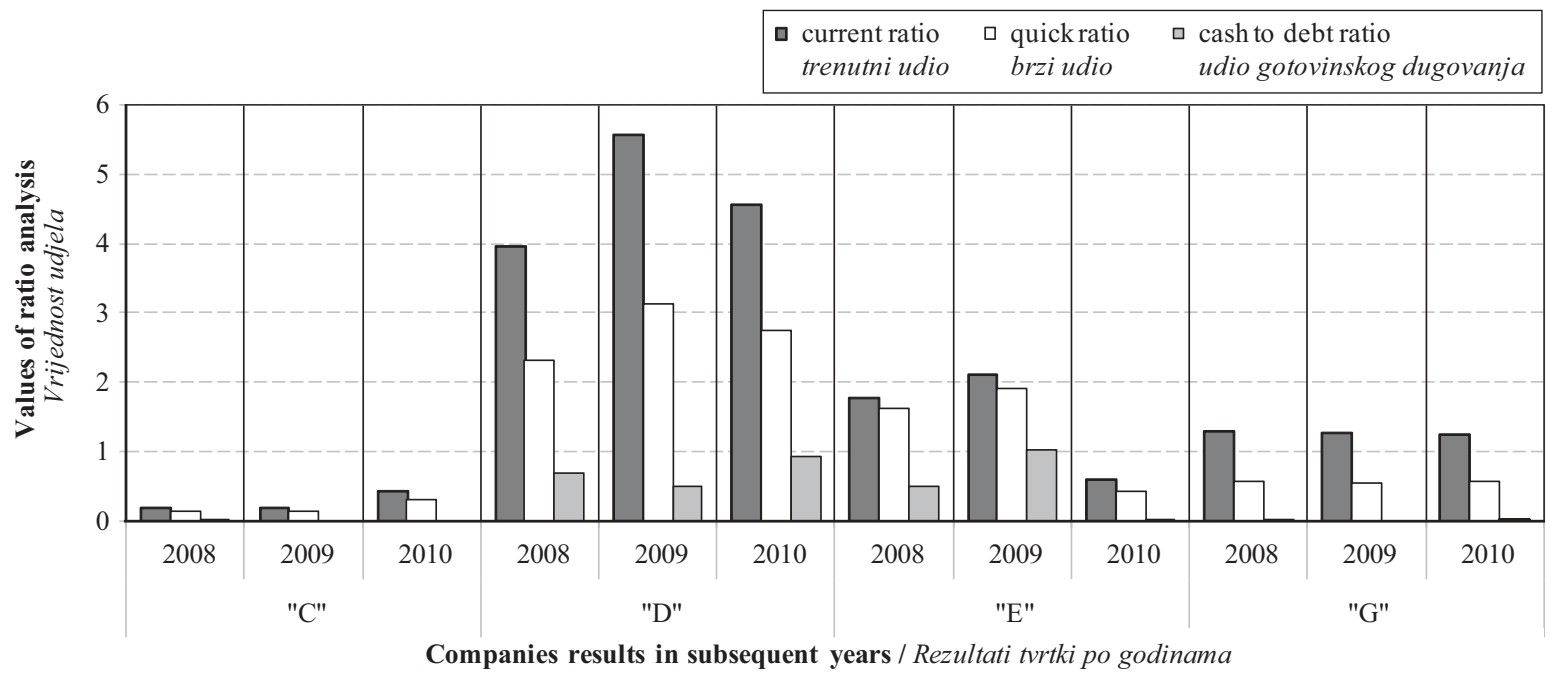

Figure 6 Results of analysis of the main liquidity ratios of wood sector companies „C”, „D”, „E”, „G” listed on Warsaw Stock Exchange

Slika 6. Rezultati analize omjera osnovne likvidnosti za „C”, „D”, „E”, „G” tvrtke drvnog sektora na Varšavskoj burzi 


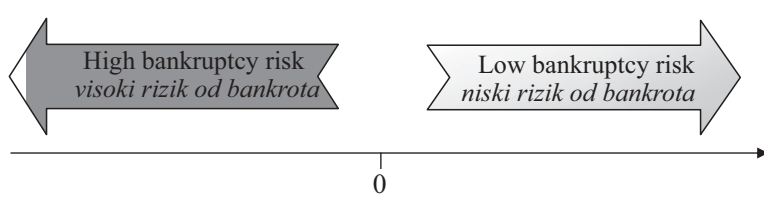

Figure 7 Companies classification in Mączyńska \& Zawadzki's method

Slika 7. Klasifikacija tvrtki prema metodi Maczynska \& Zawadzki

weights. This function structure allows qualifying the analyzed companies into two or more groups, usually:

a) group without bankruptcy risk,

b) group with bankruptcy risk or

c) group with an uncertain bankruptcy risk (Nowak, 2005).

The Mączyńska \& Zawadzki's model qualifies companies into two groups, as shown in Figure 7.

The Mączyńska \& Zawadzki's model is composed of four variables and it is calculated as follows:

$Z_{\mathrm{MZ}}=9.498 \cdot x_{1}+3.566 \cdot x_{2}+2.903 \cdot x_{3}+0.452 \cdot x_{4}-1.498$,

whereas:

$Z_{\mathrm{MZ}}$ - score of Mączyńska \& Zawadzki's polynomial;

$x_{1}-x_{4}=$ discriminant variables:

$x_{1}=$ net operating profit/assets;

$x_{2}=$ equity/assets;

$x_{3}=($ net profit + amortization $) /$ total liabilities;

$x_{4}=$ current assets/short-term liabilities (Gołębiowski and Tłaczała, 2009)

Figure 8 shows all wood sector companies listed on the Warsaw Stock Exchange as a result of Mączyńska \& Zawadzki's method analysis.

As shown in Figure 8, the lowest values of Mączyńska \& Zawadzki's polynomial were observed for „C”. The company achieved the best results in 2008 and they reached 0.521 . Decreased values of Maczyńska \& Zawadzki's method can prove weakening of economic conditions of a company. Also, the lowest value of this method was observed for „H” in 2008. In the second year of analysis, the company achieved a higher value, namely 2.713 . Unfortunately, the world econo- mic crisis affects the company results and this value has decreased to 0.837 . Quite good results of $Z_{\mathrm{MZ}}$ function was reached by „G”. Throughout the analyzed period, company results stay on a similar level ranging from 0.913 in 2008 to 1.513 in 2010 . The results of „B” are quite good, too. The best values of Maczyńska \& Zawadzki's polynomial were reached in the year 2010 by representatives of the pulp and paper industry - „E” and ,F". This could be achieved thanks to a good economic situation of these companies. Decreasing values of Mączyńska \& Zawadzki's method of „B”, „A”, „D”, „E” and „H” can be alarming. These figures may indicate deteriorating competitiveness position of the mentioned companies.

\section{CONCLUSION \\ 4. ZAKLJUČK}

The results of the analysis showed that the crisis in the global market affected the wood industry sector. As shown by EUROSTAT data, wood and wood industry companies, excluding furniture sector companies, reached in Poland in 2008 the number of about 20,000. In subsequent years, the number of these companies has decreased by about $17 \%$. In the same period, the amount of veneer sheet and wood-based panel enterprises has decreased by about $9 \%$. The number of furniture companies has increased by about $36 \%$ and the number of paper and paper products companies has increased by more than $22 \%$ in the same period. The increasing number of entities is not always followed by increasing production values. For example, in 2009 furniture production value has decreased by almost 13 $\%$ compared to the previous year, sawmilling and planning of wood production value by $30 \%$, veneer and wood-based panels by $25 \%$ and paper and paper products by $14 \%$.

KUKE SA (Export Credit Insurance Corporation Joint Stock Company) analysis shows that since 2008, the number of failing companies has increased: in 2010 668 companies went bankrupt and in 2011, as a result of insolvency, 743 entities went bankrupt.

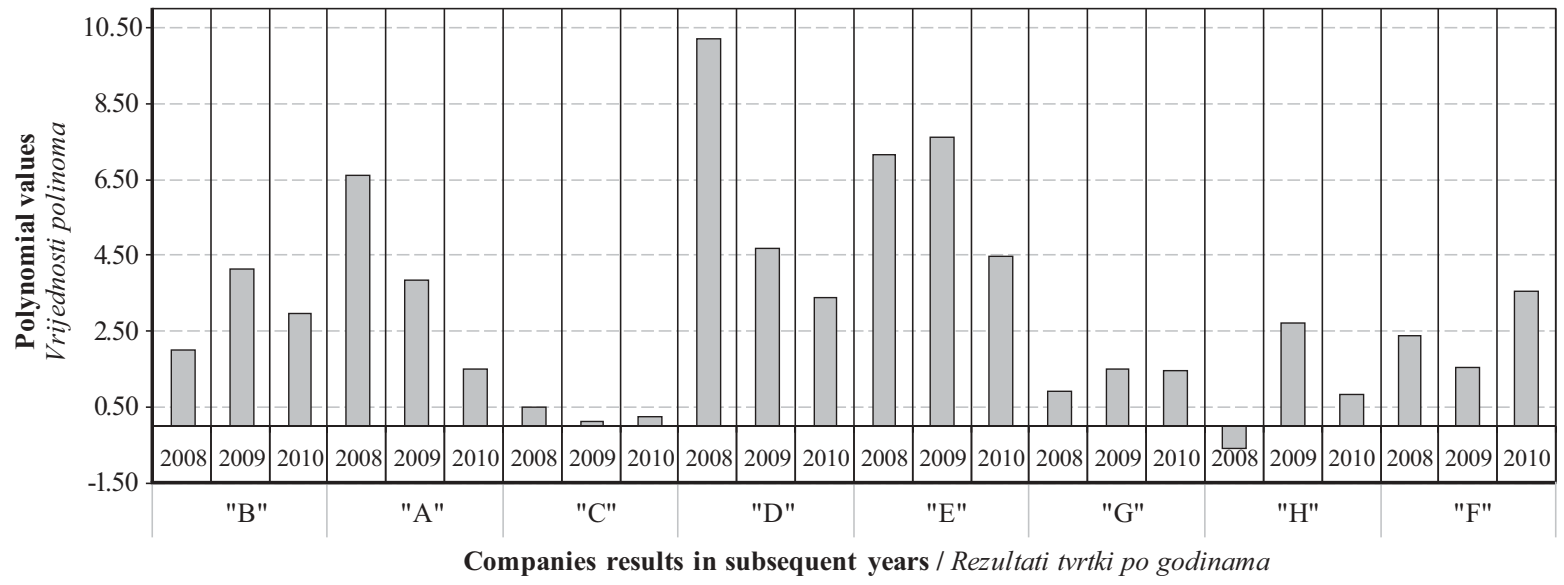

Figure 8 Results of Mączyńska \& Zawadzki’s polynomial of analyzed wood sector companies listed on Warsaw Stock Exchange

Slika 8. Rezultati Maczynska \& Zawadzki polinoma analiziranih tvrtki drvnog sektora na Varšavskoj burzi 
As a result of increasing difficulties in the market, companies had to cut costs. For example, in furniture companies salaries dropped by $19 \%$ in 2009 compared to the previous year. In other sectors salaries dropped, too: in sawmilling industry by about $25 \%$, in veneer and wood-based panel companies by about $27 \%$, in paper and paper products companies by about $14 \%$. The National Bank of Poland reports that the companies gathered at the end of 2011 at the bank accounts approximately PLN 200 billion. Considering the difficult market situation, companies warned that they would not hire new employees nor invest. This in turn could affect negatively their competitive position, but on the other hand, could help them preserve the ability to pay.

\section{Acknowledgement - Zahvala}

This paper was processed in the frame of the project APVV No. 0742-11, Kompozícia a vlastnosti vrstvovitých materiálov na baze drevných a nedrevných komponentov and of the project VEGA No. $1 / 0581 / 12$, Interakcia dreva a plastov pri tvorbe vrstvovitých materiálov lepením as the result of author's research.

\section{REFERENCES}

\section{LITERATURA}

1. Bednarski, L., 2002: Analiza finansowa w przedsiębiorstwie, PWE, Warszawa.

2. Dębski, W., 2005: Teoretyczne i praktyczne aspekty zarządzania finansami przedsiębiorstwa, PWN, Warszawa.

3. Gołębiowski, G.; Tłaczała, A.; 2009: Analiza finansowa w teorii i praktyce, Difin, Warszawa.

4. Jelačić, D.; Oblak, L.; Sedliačiková, M.; Meloska, Ž., 2006: Investicije v podjetja za predelavo lesa in proizvodnjo pohištva $\mathrm{v}$ nekaterih državah srednje in jugovzhodne Evrope, Les, vol 58., br. 1-2 / 2006, Ljubljana, Slovenija, p. 9-13.

5. Jerzemowska, M., 2004: Analiza finansowa w przedsiębiorstwie, PWE, Warszawa.

6. Michalski, G., 2005: Płynność finansowa w małych i średnich przedsiębiorstwach, PWN, Warszawa.

7. Nowak, E., 2005: Analiza sprawozdań finansowych, PWE, Warszawa.

8. Potkány, M., 2005: System for establishing intradepartmental prices in slovak wood processing industry. In: Drvna industrija, Vol. 56, No.4/2005, Denona d.o.o. Zagreb. p. 177-178.

9. Sedliačiková, M.; Jelačić, D.; Drabek, J.; Oblak, L., 2006: Suggested approach to the financial controlling in wood enterprises, Zbornik gozdarstva in lesarstva, br. 78 /2005, Ljubljana, Slovenija, 2006, p. 123-135.

10. Sierpińska, M.; Jachna, T., 2004: Ocena przedsiębiorstwa według standardów światowych, PWN, Warszawa.

11. Stępień, K., 2008: Rentowność a wypłacalność przedsiębiorstw, Difin, Warszawa

12. Stradomski, M., 2004: Zarządzanie strukturą zadłużenia przedsiębiorstwa, PWE, Warszawa

13. Tyran, M.R., 2004: Wskaźniki finansowe, Wydawnictwo: Oficyna Ekonomiczna Oddział Polskich Wydawnictw Profesjonalnych.

14. http://epp.eurostat.ec.europa.eu/portal/page/portal/ statistics/search_database

\section{Corresponding address:}

Ing. MARIANA SEDLIAČIKOVÁ, Ph.D.

Department of Business Economics Faculty of Wood Science and Technology

Technical University in Zvolen

T. G. Masaryka 24

96053 Zvolen, SLOVAKIA

e-mail: sedliacikova@vsld.tuzvo.sk 